\title{
Impact of Early Fires on Soil Physicochemical Properties in Sudan Savanna in Chad
}

\author{
Guiguindibaye Madjimbe $^{1^{*}}$, Mbaiguinam Mbailao ${ }^{2}$, Touroumgaye Goalbaye ${ }^{1}$, \\ Bansedi Ngarikla ${ }^{3}$ \\ ${ }^{1}$ Academic Institute of the Agronomic Sciences and the Environment, University of Sarh, BP 105 Sarh / Chad. \\ ${ }^{2}$ Laboratory Research Laboratory on Natural Substances, University of N'Djamena, N'Djamena, Chad. \\ ${ }^{3}$ Department of Physics-Chemistry, Faculty of Science and Technology, University of Sarh, BP 105 Sarh / Chad. \\ *Corresponding Author: Guiguindibaye Madjimbe, Academic Institute of the Agronomic Sciences and \\ the Environment, University of Sarh, BP 105 Sarh / Chad.
}

\begin{abstract}
This paper deals with the study of early fire on soil properties in the savanna. The approach chosen is based on the study of experimental plots in relation to early fires. The study was conducted in the Guirkouh forest in the Sudanian zone in Chad. The main objective of this study is to contribute to the knowledge of the effects of early fires on the physicochemical properties of the soil in the savanna. The research work was carried out in an experimental system covering 0.25 ha. Three fuel treatments were considered in addition to the control in the early fire regime. The results showed no significant difference in the rate of progression and in the intensity of the fire. And no significant differences were observed between the profiles either before or after the passage of fire. Similarly, no interaction effect of these factors on the particle size distribution was observed. However, a greater nutrient enrichment of the surface layers was observed. Depending on soil sampling depth, a 1\%, 2\% and 5\% decrease in total phosphorus (Pt) was also observed for 0-5 cm horizons, respectively; $5-10 \mathrm{~cm}$ and $10-15 \mathrm{~cm}$. Overall, the study shows that pH, total Carbon $(\mathrm{Ct})$, the ratio $\mathrm{C} / \mathrm{N}$ and total Nitrogen $(\mathrm{Nt})$ not significantly varied $(P>0.05)$ during the three years of application of early fire.
\end{abstract}

Keywords: Soil, Early fire, Intensity, Physicochemical properties, Savannah, Chad.

\section{INTRODUCTION}

Fire is a seasonal phenomenon prevalent in savannah ecosystems [1]. In Chad, as throughout the African savannah areas, bush fires are caused by various causes, including the preparation of new agricultural plots, regeneration of pastures, protection of dwellings and ceremonial rituals. There are also accidental fires due to smoking of hives or carbonization. The importance given to bush fires in Africa is also justified by the fact that fires are used by managers of the environment for management reasons. Fires can also occur through negligence due to favorable climatic conditions [2]. Early fires are lit at the end of the rainy season to improve pasture production and maintain the composition and specific richness of herbaceous plants [3]. These fires, often intentional, burn a still active vegetation with a relatively high water content. This type of fire is considered to be the least harmful because it consumes less plant material. In general, the fire progresses slowly and many saved organisms will allow an active recovery during the first rainfall or simply during a rise in the hygrometry [4]. In Sudan savannahs and particularly in Chad, early fires are officially approved and are generally observed between October and November. Fire, by its action, induces changes in the physical and chemical properties of the soil. The physical impact of fire on the soil includes the destruction of the structure and the reduction of the soil water holding capacity [5]. Some important physical characteristics in the soil are affected by the heating of the soil due to fires [6]. These features include soil color, texture and $\mathrm{pH}$. The color of the soil is deeply altered after a fire with a high concentration of fuel [7]. The ash from the combustion is gray or black in the case of a moderate fire. The color of soils subjected to fires with a temperature of at least $600^{\circ} \mathrm{C}$ with 45 minutes of exposure turns red [8]. Soil texture components (sand, silt and clay) generally react at very high temperatures on the soil surface [6]. The clay remains the sensitive fraction, already at $400^{\circ} \mathrm{C}$, the hydration and the lattice structures of the clay begin to collapse and then between 700 and $800^{\circ} \mathrm{C}$., the complete destruction of 
the internal structure of the clay can occur [9]. In addition, fire can reduce porosity and thus increase soil $\mathrm{pH}$, as well as exchangeable bases [10]. The accumulation of ash rich in potassium, magnesium, sodium hydroxide, and calcium carbonate could be the cause of this increase [11]. In addition, high temperatures lead to denaturation of soil colloids and release hydroxyl ions which may contribute to lower $\mathrm{pH}$ [9]. In addition, loss of soil cover also exposes it to crusts, thus destroying soil structure [12]. As for the chemical impact of fire on the soil, [14] find that fire influences the dynamics of nutrients in soils of savannah ecosystems. Depending on the severity of the fire, changes in soil and its components can be beneficial or detrimental to the entire ecosystem. Frequent and late fires can have destructive effects on soil properties by destroying organic matter in vegetation and litter on the soil surface [14]. However, the impact of fire on soils can be beneficial when the fire is not too intense and the heating of the soil is brief [15]. In addition to raising the temperature, fires affect soil organic matter, soil chemistry (ash content, $\mathrm{pH}$ ) and the extent of erosion. Much of the work on fires in Africa has affected its impact on vegetation dynamics and behavior. As a result, little information is available on the effect of fuel quantity and seasonal fires on soil physicochemical properties. This research focuses on the effects of early fires on nutrients that experience the most immediate effects of fire, resulting in significant changes in their availability to the soil.

\section{Material AND MethodS}

\subsection{Presentation of the Study Area}

The fieldwork took place in the classified forest of "Guirkouh", which means dense forest or bush of trees in "Sara", language of this locality. The classified forest of "Guirkouh" is located in Koumogo township, Barh-Kôh department and Moyen-Chari region in southern Chad. It is located between latitude $8^{\circ} 55^{\prime} 19^{\prime \prime}$ and latitude $9^{\circ} 00^{\prime} 05^{\prime \prime}$ North and longitude $18^{\circ} 19^{\prime} 44^{\prime \prime}$ and $18^{\circ} 25^{\prime} 24^{\prime \prime}$ East, and distant about twenty kilometers southwest of the city of Sarh, capital of said department and of the said region (Figure 1). Its altitude varies between 326 and $388 \mathrm{~m}$. The soils are tropical ferruginous types. The climate is Sudanian, with a dry season from October to March and a rainy season from April to September. The site is located on a clear forest formation at Anogeissus leiocarpa and mainly of wooded and shrub savannah at Terminalia avicennioides and Piliostigma thonningii. The Barh-kôh River that crosses this forest is bordered by riparian vegetation and the valleys include forest galleries with species such as Mitragyna inermis and Diospyros mespiliformis. The herbaceous stratum is dominated by Loudetia annua and Andropogon gayanus. The average annual rainfall for the last five years is $1099 \mathrm{~mm}$ (ASECNA-Agency for the Safety of Air Navigation in Africa and Madagascar). The average temperature is $28^{\circ} \mathrm{C}$. The average of the maximum temperatures is $33^{\circ} \mathrm{C}$ and that of the minimum temperatures is $22^{\circ} \mathrm{C}$. The surrounding topography is quasi flat, the altitude of which varies between 326 and $388 \mathrm{~m}$. The winds are dominated by the harmattan in the dry season and the monsoon that generates the rains. The atmospheric humidity, which is very low in February and March, gradually increases from April onwards with the rise of the inter-tropical front to reach its peak in August. In the canton of Koumogo, agriculture is the main activity and source of income for the majority of the population.

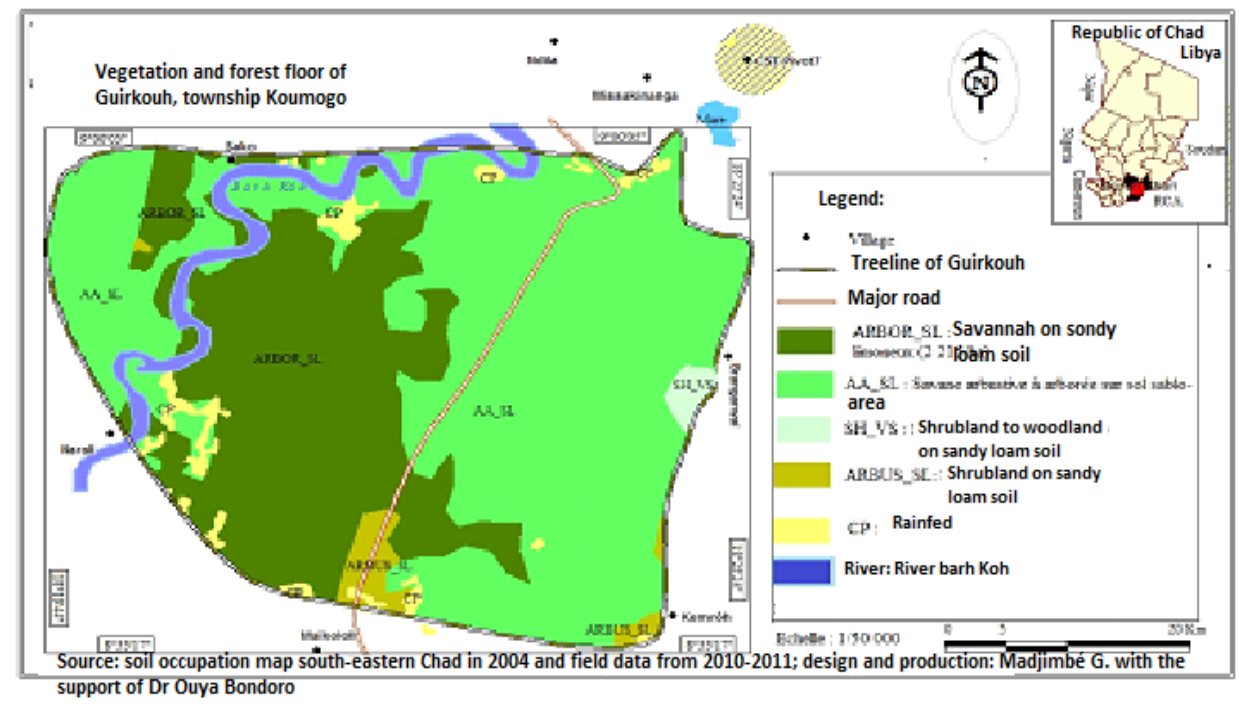

Figure1. Location and map of study site 


\subsection{Material}

Our study material consists of soil and plant fuels to measure herbaceous biomass and its moisture content. Tools such as Herbaceous Biomass Estimates and GPS (Global Positioning System) were used.

\subsection{Methods}

\subsubsection{Fuel Characteristics and Behavior of the Fire}

In this study, fuel characteristics and fire behavior were examined in relation to wood cover, air humidity and wind speed. During the fire experiments, the meteorological data (wind speed, humidity and air temperature) were recovered at the ASECNA weather station Sarh airport ( $9^{\circ} 07^{\prime} 49^{\prime \prime}$ North and $18^{\circ} 22^{\prime} 43^{\prime \prime}$ East). In terms of fuel characteristics, parameters such as herbaceous biomass $\left(\mathrm{kg} . \mathrm{m}^{2}\right)$, moisture content (\%) were measured. Wood cover was also estimated. The amount of fuel (biomass) was obtained by cutting the herbaceous biomass manually at $10 \mathrm{~cm}$ from the soil in each plot except those of the controls. The weight of the fuel in each plot was then taken and samples taken for the determination of the dry weight after a passage for 48 hours in an oven at $105^{\circ} \mathrm{C}$. On the basis of the weight of the dry matter of each plot, three treatments (Figure 2) were considered in the early fire regime following the method of [4]:
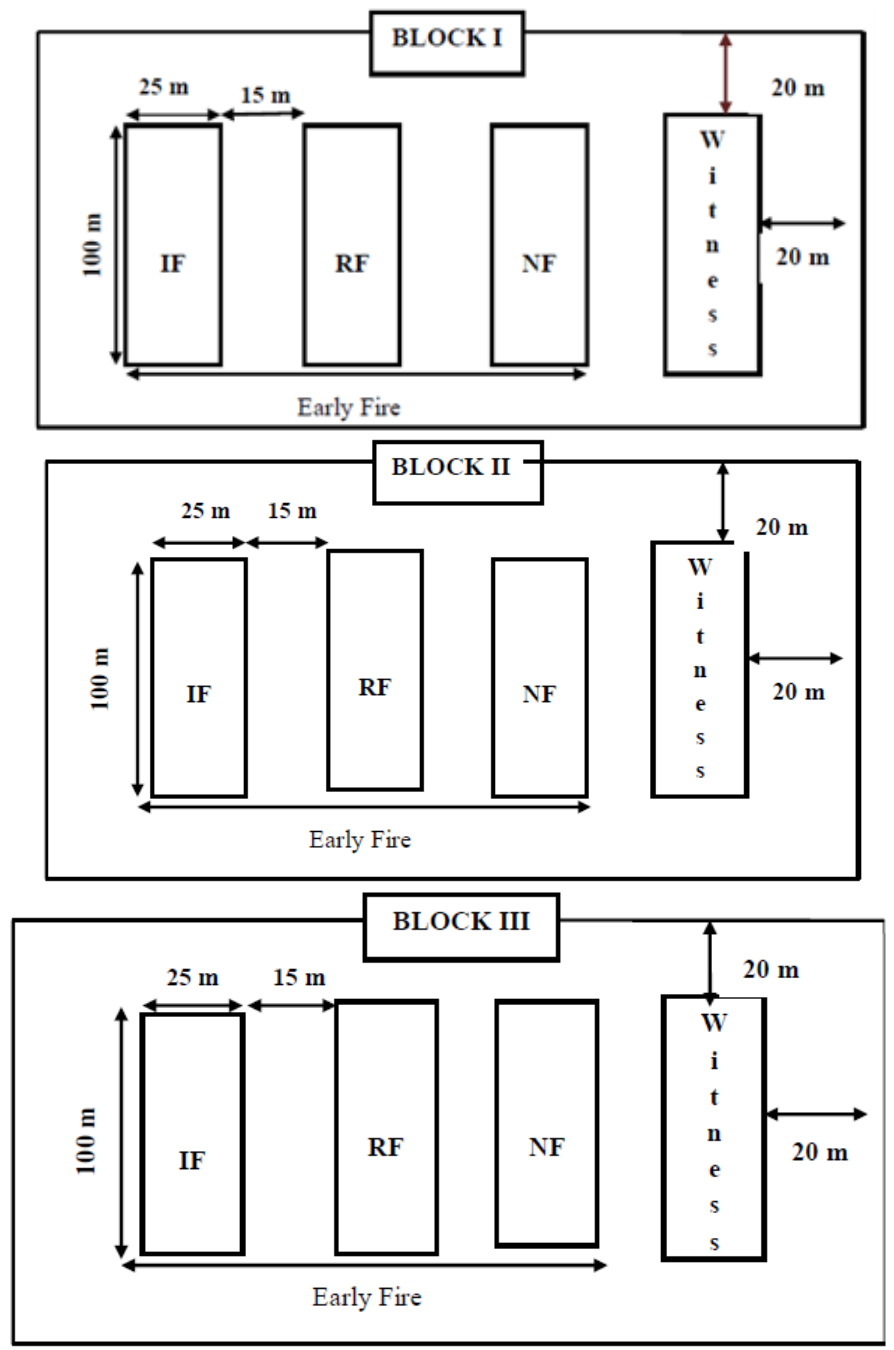

IF: Increased Fuel; RF: Reduced Fuel ; NF: Normal Fuel

Figure2. Experimental study facility installed in the Guirkouh forest

Initial Fuel (IF), it was cut and evenly distributed to ensure continuity of the fire;

Decreased Fuel (DF), half of the original fuel was subtracted and removed from that parcel;

Added Fuel (AF), the second half subtracted in decreased fuel was added to the original fuel, and the whole was distributed homogeneously. 
The moisture content of the fuel (\%) was then calculated using the formula:

$H=\frac{\mathrm{PH}-\mathrm{PS}}{\mathrm{PH}} \times 100$

With H: Fuel moisture; PH: Wet fuel weight; PS: Dry weight of fuel.

The herbaceous species and the wood cover were evaluated in abundance-dominance, according to the phyto-sociological method of Braun-Blanquet. The fire behavior parameters (speed of propagation (m.s-1), temperature $\left({ }^{\circ} \mathrm{C}\right)$, fire intensity $\left(\mathrm{Kj} \mathrm{m}^{-1} \mathrm{~S}^{-1}\right)$ were also evaluated. using a laser pyrometer with a sensitivity of between $-50^{\circ} \mathrm{C}$ and $1000^{\circ} \mathrm{C}$ and a resolution of 30: 1 (model TP6 TROTEC, MIS instrumentation, France). The operation consisted to scan the fire central front with the help of pyrometer. The temperature is automatically displayed on a screen and several measurements have been carried out in each plot following the progress of the fire. The fire propagation speed is obtained by recording the time taken by the fire front of the fire to cover a distance of $20 \mathrm{~m}$, operators equipped with chronometers were stationed every $20 \mathrm{~m}$ to increase the time of passage of the fire. The values of these parameters made it possible to calculate the intensity of the fire using the " equation proposed by Byram: $I=H . w . r$

Where $\mathrm{I}$ is the intensity of the fire $\left(\mathrm{kJ}^{-1} \mathrm{~s}^{-1} \mathrm{~m}^{-1}\right) ; \mathrm{H}=$ the constant expressing the heat released $\left(\mathrm{kJ}^{\mathrm{k}} \mathrm{kg}^{-1}\right)$; $\mathrm{w}$ is the mass of consumed fuel per unit area $\left(\mathrm{kg} \cdot \mathrm{m}^{-2}\right) ; \mathrm{r}=$ speed of advance $\left(\mathrm{m} \cdot \mathrm{s}^{-1}\right)$.

To calculate the intensity of the fire, we adopted the values of heat quantity released at the time of the combustion of herbaceous while a fire applied against wind direction, and estimated at $17781 \mathrm{Kj} . \mathrm{kg}^{-1}$ [16].

\subsubsection{Sampling of Soil Samples}

Concerning the soil, the samples were collected before and immediately after the passage of the fire. In the control plot, only one sample is taken each year as the fire is not applied. Prior to collection, the litter was first discarded and the samples were then taken at five points following the two diagonals of each plot. Three horizons (depths) were considered $(0-5,5-10$ and 10-15 $\mathrm{cm}$ ) because the main changes occur at the surface soil level. Composite samples were constructed by mixing the soil catch per horizon. The soil samples were dried, sieved to $2 \mathrm{~mm}$ and packaged in plastic bags. Physicochemical analyzes were carried out at the Laboratory of Geology, Geomorphology and Remote Sensing of the University of N'Djamena in Chad using the following methods:

$>$ The $\mathrm{pH}_{\text {water }}$

$>\mathrm{pH} \mathrm{H}_{2} \mathrm{O}$ from a suspension of soil in water by the electrometric method at $\mathrm{pH}$ meter with glass electrode;

The soil particle size

The granulometric analysis in three fractions is carried out on the fine earth previously sieved at 2000 $\mu \mathrm{m}$. Then the organic matter is completely destroyed by hydrogen peroxide $\left(\mathrm{H}_{2} \mathrm{O}_{2}\right)$ and the clay is dispersed by sodium hexametaphosphate (HMP). This chemical destruction is completed by mechanical destruction. Thus, the mixture obtained is stirred on a reciprocating stirrer in the presence of 5 glass beads for $1 \mathrm{~h} 30 \mathrm{~min}$. The suspension thus obtained is then screened using a water jet sieve having two 200 and $50 \mu \mathrm{m}$ sieves. Three fractions are then recovered: the first fraction brings together the particles having a size greater than $200 \mu \mathrm{m}$ (between $200 \mu \mathrm{m}$ and $2000 \mu \mathrm{m}$ ), the second fraction is between $50 \mu \mathrm{m}$ and $200 \mu \mathrm{m}$, and the third fraction groups the elements below $50 \mu \mathrm{m}$. These fractions obtained are subjected to slow evaporation in an oven at a temperature of $60^{\circ} \mathrm{C}$. They are then recovered by scraping and then weighed.

\section{The total carbon}

The determination of the total carbon content consists of a cold oxidation of the soil carbon with $1 \mathrm{~N}$ potassium dichromate $\left(\mathrm{K}_{2} \mathrm{Cr}_{2} \mathrm{O}_{7}\right)$ in the presence of concentrated sulfuric acid $\left(\mathrm{H}_{2} \mathrm{SO}_{4}\right)$. The excess of the bichromate is assayed by Mohr Fe( $\left(\mathrm{SO}_{4}\right)_{2}(\mathrm{NH})_{2}$ salt in the presence of a colored indicator. The organic matter content was determined from the organic carbon content, using the multiplier factor of 1.724 .

Determination of total Phosphorus (Pt), total nitrogen (Nt) and total Potassium (Kt) 
$>$ The soil samples are digested in a mixture of sulfuric acid, selenium and hydrogen peroxide $\left(\mathrm{H}_{2} \mathrm{SO}_{4}-\mathrm{Se}-\mathrm{H}_{2} \mathrm{O}_{2}\right)$ at $450^{\circ} \mathrm{C}$. For 4 hours. Subsequently, the Nt, Pt elements were subsequently determined after reading on the spectrophotometer and for $\mathrm{Kt}$, reading was carried out using a flame photometer.

Assimilable Phosphorus

The extraction of assimilable phosphorus consists in extracting the phosphorus forms which are soluble in the acids, in large part those linked to calcium, and a portion bound to aluminum and iron by means of a mixed solution of hydrochloric acid $(\mathrm{HCl})$ to $0.025 \mathrm{M}$ and $0.03 \mathrm{M}$ ammonium fluoride $\left(\mathrm{NH}_{4} \mathrm{~F}\right)$.

\section{$>$ The Cation Exchange Capacity (CEC)}

The soil was washed with ethyl alcohol to remove the excess of the salts. The absorbent complex, after displacement of the exchangeable bases, is saturated with ammonium $\left(\mathrm{NH}^{4+}\right)$ of the normal solution of ammonium acetates. The excess $\mathrm{NH}^{4+}$ is removed by the ethyl alcohol and then the $\mathrm{NH}_{4}$ fixed on the absorbent complex is displaced by a normal solution of $\mathrm{CaCl}_{2}$ and then titrimetrically assayed after distillation.

\section{RESUltS}

\subsection{Fuel Characteristics and Fire Behavior}

Overall, the average fuel quantity for the three years of study was $0.38 \pm 104 ; 0.75 \pm 32$ and $1.6 \pm$ 0.51 t.ha $^{-1}$, respectively for the treatments DF (Decreased Fuel), IF (Initial Fuel) and FA (Fuel Added) (Figure 3). The data analysis series performed indicated interannual variations. The amounts of CI treatment fuel are statistically similar in first and third year of study and are lower than CA (Figure 3). In the second year, however, the quantities present in the NF treatment are statistically higher than in RF. In addition, the average fuel moisture of the three years of study remained substantially the same for the different treatments (Figure 4). The average values are 51.6 $\pm 3.85 ; 50.6 \pm 6.05 ; 41.6 \pm 3.16$ respectively for DF, IF and FA (Figure 4). However, interannual variations were noted. Contrary to what was observed in 2016, during the first two years, the moisture content of the biomass varied significantly between the plots of land (Figure 4). The highest fire temperature recorded was $650 \pm$ 44.56 in the IF plot during the third year of study (Figure 5).

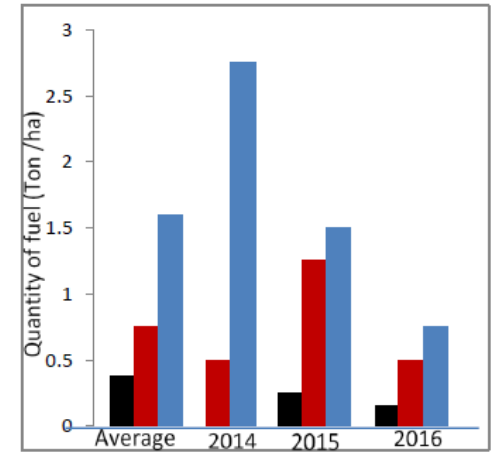

Figure3. Quantity of fuel

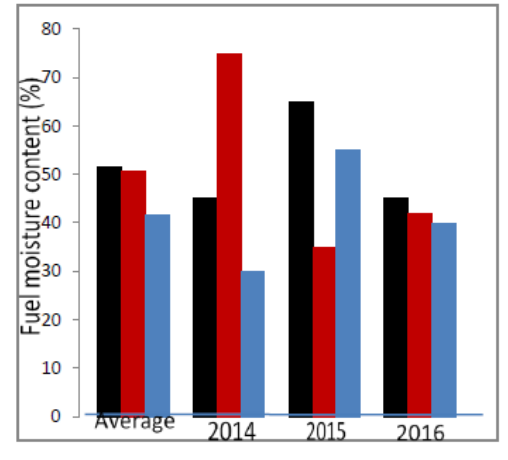

Figure4. Fuel moisture content

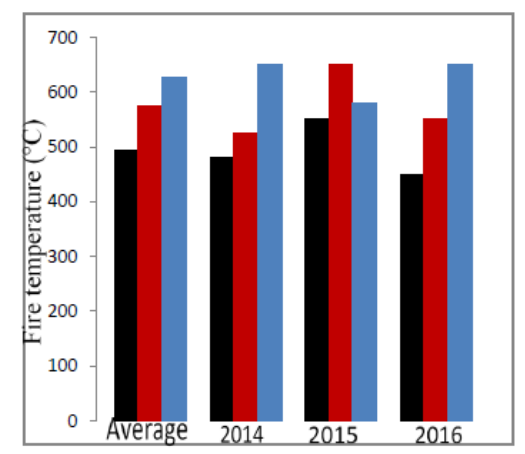

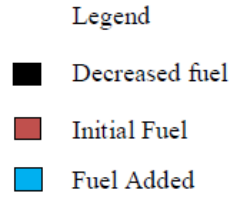

Figure5. Fire temperature

However, the statistical tests do not indicate a significant difference between the fuel treatments, and between years $(F[2,9]=1.356, P=0.424, \eta 2=0.319)$. Similarly, no significant difference $(F[2,9]$ 
$=0.956, \mathrm{P}=0.433, \Pi 2=0.244$ ) was also noted, neither in the rate of progression of the fire (Table 1) nor in its intensity (Table 2). Fire intensity varied significantly only in the first year of study.

Table1. Fire propagation speed in plots subjected to different fuel treatments

\begin{tabular}{|c|c|c|c|c|c|c|c|c|c|c|c|c|}
\hline \multirow{3}{*}{$\begin{array}{l}\text { Propagation } \\
\text { speed }(\mathrm{m} / \mathrm{s})\end{array}$} & \multicolumn{3}{|c|}{2014} & \multicolumn{3}{|c|}{2015} & \multicolumn{3}{|c|}{2016} & \multicolumn{3}{|c|}{ Average } \\
\hline & $\mathrm{DF}$ & IF & FA & DF & IF & FA & DF & IF & FA & DF & IF & FA \\
\hline & 0.03 & 0.07 & 0.04 & 0.08 & 0.04 & 0.05 & 0.02 & 0.04 & 0.03 & 0.04 & 0.05 & 0.04 \\
\hline
\end{tabular}

Table2. Intensity of fire in plots subjected to different fuel treatments

\begin{tabular}{|c|c|c|c|c|c|c|c|c|c|c|c|c|}
\hline \multirow{2}{*}{$\begin{array}{c}\text { Intensity of } \\
\text { fire } \\
(\mathrm{Kj} / \mathrm{m} / \mathrm{s})\end{array}$} & $\mathrm{DF}$ & $\mathrm{IF}$ & $\mathrm{FA}$ & $\mathrm{DF}$ & $\mathrm{IF}$ & $\mathrm{FA}$ & $\mathrm{DF}$ & $\mathrm{IF}$ & $\mathrm{FA}$ & $\mathrm{DF}$ & IF & FA \\
\cline { 2 - 13 } & 50 & 60 & 180 & 40 & 100 & 130 & 15 & 20 & 40 & 35 & 60 & 116.6 \\
\hline
\end{tabular}

DF: Decreased Fuel

IF:_nitial Fuel

FA:Fuel Added

\subsection{Models for Predicting Fire Behavior}

The fire behavior prediction models presented in Table 1 show that wood cover and fuel moisture account for $63 \%$ of the variation in the velocity of propagation (PV) while the temperature and intensity of the fire are predictable. With the amount of fuel, this explains respectively $64 \%$ and $88.6 \%$ of the variations of the temperature and the intensity of the fire.

The result of the regression equation for the prediction of fire propagation velocity (PV), temperature, and fire intensity of fire is given in the Table 3. The prediction parameters are: fuel quantity (FQ), vegetation cover $(\mathrm{VC})$, fuel moisture $(\mathrm{FM}), \mathrm{ESE}=$ estimated standard error, $\mathrm{r}^{2}=$ determination coefficient.

Table3. Regression equation for the prediction of fire propagation velocity $(P V)$, temperature, and fire intensity. The prediction parameters are: fuel quantity $(F Q)$, vegetation cover (VC), fuel moisture $(F M), E S E=$ estimated standard error, $r^{2}=$ determination coefficient.

\begin{tabular}{|c|c|c|c|}
\hline Variables & ESE & $\mathrm{r}^{2}$ & $\mathrm{P}$ \\
\hline $\mathrm{VP}=0.163-3.174 \mathrm{CV}-1$, & 0.0139 & 0.624 & 0.05 \\
\hline $\mathrm{T}=3.245+2.985 \mathrm{FQ}+1.59 \mathrm{FM}$ & 62.456 & 0.643 & 0.05 \\
\hline $\log (\mathrm{I})=1.437+5.641 \mathrm{QC}-0.206 \mathrm{VC}$ & 31.419 & 0.886 & 0.002 \\
\hline
\end{tabular}

\subsection{Fire and Particle Distribution in the Soil}

The results of the particle size analysis are presented in terms of fuel processing (Figure 6), pre- and post-fire sampling (Figure 7), and soil sampling depth (Figure 8). The soil texture in the studied plots is sandy-loamy with a dominance of the sandy fraction. No significant difference was observed between the profiles, either before or after the fire. Similarly, no interaction effect of these factors on the particle size distribution was observed. However, the results indicate that the soil content in coarse silt is significantly higher $\left(\mathrm{F}_{[3,32]}=5.484, \mathrm{P}=0.002\right)$ in the fuel plots added and decreased compared to the control and initial fuel plots. In general, the proportion of coarse sands was lower than that of fine and coarse sands.

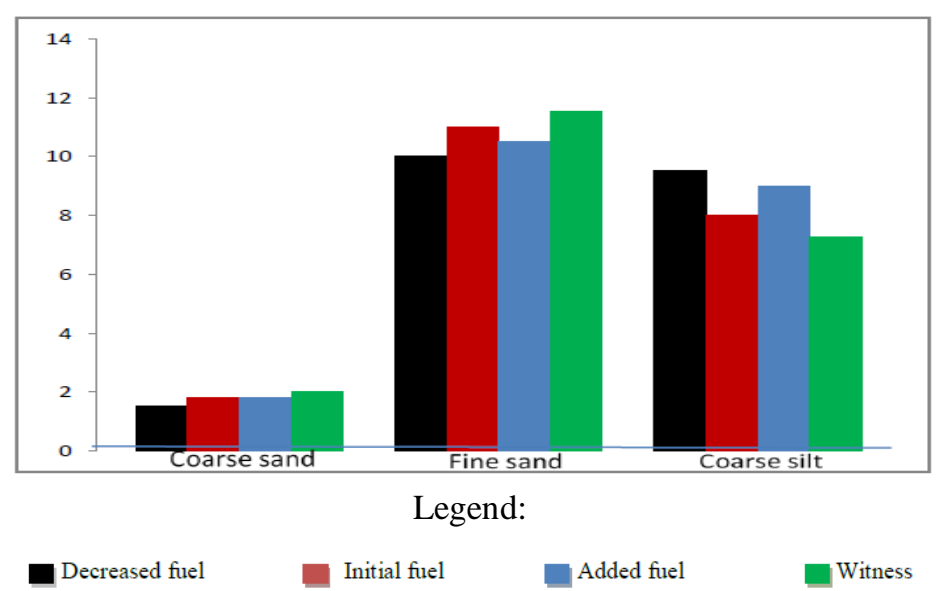

Figure6. Fuel Treatment 


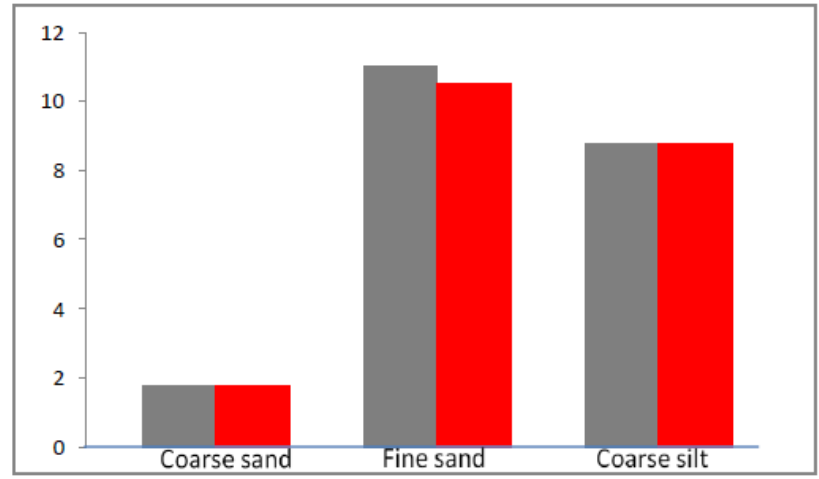

Legend:

Before fire

After fire

Figure7. Environment before fire and after fire

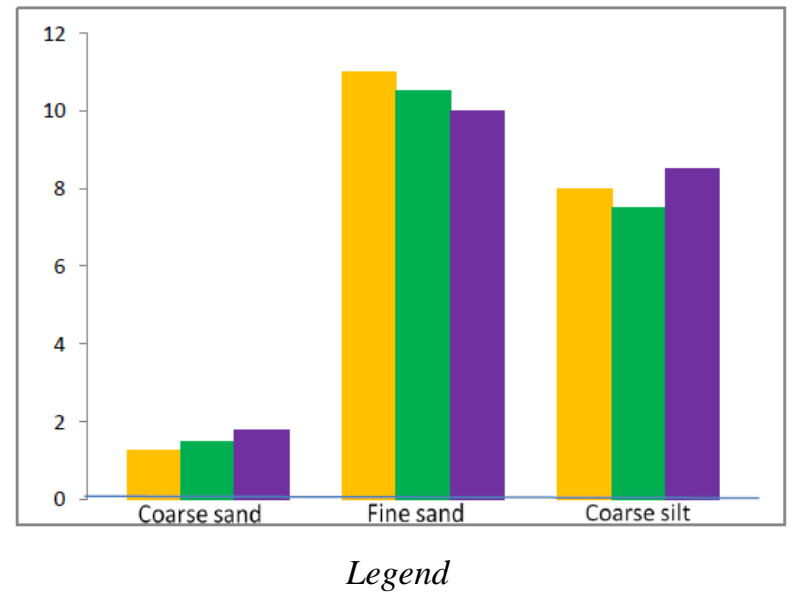

Depth $[0-5 \mathrm{~cm}] ; \quad$ Depth $[5-10 \mathrm{~cm}]$; Depth $[10-15 \mathrm{~cm}]$

Figure8. Depth of soil sampling on soil grain size

\subsection{Effect of Early Fire on the Ground}

Overall, $\mathrm{pH}$, total carbon $(\mathrm{Ct})$, ratio $(\mathrm{C} / \mathrm{N})$, total nitrogen $(\mathrm{Nt})$ and cation exchange capacity $(\mathrm{CEC})$ did not vary significantly $(\mathrm{p}>0.05)$ during the three years of early fire application. Average values of $\mathrm{pH}$, total carbon $(\mathrm{Ct})$ and Carbon-nitrogen ratio in all the fuel treatments respectively oscillate around 6; 5 $\mathrm{g} / \mathrm{kg}$ and 16 . Those total phosphorus (Pt) and cation exchange capacity (CEC) were $73.51 \mathrm{mg} / \mathrm{kg}$ and $3.68 \mathrm{Cmol} / \mathrm{kg}$, respectively. The results also showed that the sampling depth has a significant effect for $\mathrm{pH}$, total carbon $(\mathrm{Ct})$, carbon-nitrogen ratio, Total Nitrogen $(\mathrm{Nt})$ and Cation Exchange Capacity $(\mathrm{CEC})$. The $\mathrm{pH}$ value decreased by 1.10 from the $0-5 \mathrm{~cm}$ horizon and by 0.16 from the $5-10 \mathrm{~cm}$ horizon by $10-15 \mathrm{~cm}$. The $\mathrm{Ct}, \mathrm{Nt}$ and CEC contents are similarly weak at the $5-10 \mathrm{~cm}$ and $10-15 \mathrm{~cm}$ horizons compared to the $0-5 \mathrm{~cm}$ horizon. However, the fire resulted in a slight decrease in carbonnitrogen ratio in the superficial horizons. The fire event had no significant effect on the carbon contents of the soil. On the other hand, carbon-nitrogen ratio has significantly increased after the passage of fire. In addition, the values of $\mathrm{pH}, \mathrm{Nt}$ and $\mathrm{Pt}$ significantly decreased after the passage of fire. However, no significant interaction between the different factors (Treatment $x$ Depth, Treatment $\mathrm{x}$ Test, Treatment $\mathrm{x}$ Depth $\mathrm{x}$ Test) was observed in the different soil parameters. On the other hand, the $\mathrm{pH}, \mathrm{Ct}, \mathrm{CEC}$ values showed a highly significant interannual variation.

\subsection{Effect of Fire Protection on Soil Chemical Parameters}

The results of statistical analysis of soil parameters in fire-protected plots (Witness) indicated that $\mathrm{pH}$, carbon-nitrogen ratio varied significantly depending on the depth of soil sampling (Table 4). The $\mathrm{pH}$ value increased from $6.16 \pm 0.11$ to $6.00 \pm 0.12$ and $6.29 \pm 0.13$ for depths $0-5 \mathrm{~cm}, 5-10 \mathrm{~cm}$ and $10-15$ $\mathrm{cm}$ respectively, while the ratio $\mathrm{C} / \mathrm{N}$ are for the same depths, increased from $14.86 \pm 1.18$ to $16.45 \pm$ 1.47 then to $16.83 \pm 1.27 \mathrm{Cmol}$, respectively. $\mathrm{PH}$ and $\mathrm{Nt}$ values decreased over the three years while $\mathrm{Ct}, \mathrm{Pt}, \mathrm{CEC}$ and carbon-nitrogen ratio levels increased in the first and third year of study. 
Table4. Interannual variation of soil properties of protected plots in Sudanian savannah in Chad (average \pm standard error)

\begin{tabular}{|c|c|c|c|}
\hline Ground parameter & Year 2014 & Year 2015 & Year 2016 \\
\hline $\mathrm{pHeau}$ & $5.983 \pm 0.065$ & $4.890 \pm 0.021$ & $4.741 \pm 0.029$ \\
\hline $\mathrm{Ct}(\mathrm{g} / \mathrm{kg})$ & $6.41 \pm 0.45$ & $7.23 \pm 0.36$ & $9.16 \pm 0.21$ \\
\hline $\mathrm{Nt}(\mathrm{g} / \mathrm{kg})$ & $0.57 \pm 0.04$ & $0.39 \pm 0.02$ & $0.34 \pm 0.04$ \\
\hline $\mathrm{C} / \mathrm{N}$ & $8.904 \pm 0.284$ & $7.804 \pm 1.998$ & $10.904 \pm 0.522$ \\
\hline $\mathrm{Pt}(\mathrm{mg} / \mathrm{kg})$ & $63.815 \pm 6.049$ & $63.419 \pm 6.049$ & $78.514 \pm 1.141$ \\
\hline $\mathrm{CEC}(\mathrm{Cmol} / \mathrm{kg})$ & $1.892 \pm 0.126$ & $1.8821 \pm 0.131$ & $3.916 \pm 0.021$ \\
\hline
\end{tabular}

\subsection{Effect of Fire on the Dynamics of Phosphorus and Nitrogen}

During the two consecutive years, the fire had no significant effect ( $p>0.05)$ on the availability of mineral nitrogen and potassium content. However, interannual variations are observed. $\mathrm{NH}_{4}{ }^{+}$content decreased by approximately $65 \%$ between 2014 and 2015, including in the control plot. However, in the last year, the $\mathrm{NO}_{3}{ }^{-}$content has increased by more than $25 \%$. Similarly, with the exception of the control plot where a slight increase of $4 \%$ was observed, the total potassium soil (Pt) content decreased by $4 \%, 2 \%$ and $9 \%$ respectively for FD, IF and FA. Depending on the soil sampling depth, a decrease of $1 \%, 2 \%$ and $5 \%$ of total phosphorus $(\mathrm{Pt})$ was also observed for $0-5 \mathrm{~cm}$ horizons respectively; $5-10 \mathrm{~cm}$ and $10-15 \mathrm{~cm}$.

In addition, there is a decrease in assimilable phosphorus (Pass) with depth. On the other hand, over the 2014-2015 period and for the same horizon, the Pass content increased by $12 \%, 16 \%$ and $6 \%$ respectively in the $0-5 \mathrm{~cm}$ horizons; $5-10 \mathrm{~cm}$ and $10-15 \mathrm{~cm}$. The fire thus induced a significant increase in the quantities of assimilable phosphorus during the first year of study. The levels of assimilable phosphorus also decreased with the depth of soil sampling. The first two soil horizons (0$5 \mathrm{~cm}$ and $5-10 \mathrm{~cm}$ ) have significantly higher values than the $10-15 \mathrm{~cm}$ horizon.

\section{DisCUSSIONS}

\subsection{Fuel Characteristics and Fire Behavior}

The results of the study showed an interannual variation in the amount of fuel. This could be explained by the variability in the amount and distribution of precipitation observed during the study. Despite fuel variation, there was no significant difference in fire intensity and propagation velocity. The highest temperatures measured reached $657 \pm 36^{\circ} \mathrm{C}$. Similar results were recorded in Sudanese woodland savanna in Burkina Faso [4]. Similarly, studies have generally reported that fire temperatures increase with the amount of fuel [17]. According to these authors, fire behavior is determined by the physical properties of the fuel and the meteorological parameters. Indeed, the wind favors the supply of oxygen to the fire and thus stimulates the heat transfer by conduction or radiation, and the heating of the fuel at the front of the fire [18]. It is known that wind direction and velocity affect the spread of fire [19] by tilting the angle of the flames to areas not yet reached by fire. However, the climatic conditions that prevailed during this study were normal and cannot be incriminated. The cutting of biomass and its homogeneous distribution in the plots could explain the absence of difference in fire behavior. This practice has led to a better quantitative and spatial distribution of the fuel, favoring a more continuous combustion and a constant speed of fire. Overall, the fire behavior characteristics found in this study are comparable to those reported in woodland savannah ecosystems in West Africa [4]. Models for predicting fire behavior can be defined by integrating environmental and climatic parameters. These prediction models, developed in this study, have shown that the rate of fire progression, temperature, and intensity can be explained based on wood cover, fuel quantity, and moisture 'air. They are statistically significant and confirm those obtained in the Togo forest [18]. They can therefore be used to predict fire behavior in the Sudanian zone.

\subsection{Fire and Particle Distribution in the Soil}

The analysis of the results of the particle distribution shows that, in general, the fire has no effect on the texture of the soil. This result corroborates those of [4], who showed that fire does not significantly affect the texture of the soil. The main components of soil texture (sand, silt and clay) have low sensitivity to heat and are not usually affected by fire as most fires do not reach the temperature required to cause significant changes in physical properties of the soil. This is particularly 
true for early savanna fires, which heat the soil only briefly and superficially [18]. The most sensitive fraction is clay, which begins to experience the effects of fire from $400{ }^{\circ} \mathrm{C}$; however, sand and silts that consist of quartz particles have a melting point of $1414^{\circ} \mathrm{C}$ [4]. Under these conditions, fire temperatures generally recorded in savannah are rarely high enough to modify clays beyond a few centimeters of the soil surface. However, the destruction of the soil cover and consequent loss of soil protection further exposes the soil to erosion, crusting and loss of nutrients by leaching. Coarse salt content was higher in the Fuel Added (CA) and the Decomposed Fuel (CD) plots. These differences could probably be due to the initial soil texture of the plots in question, their organic matter content, and the moisture content of the fuel, or the duration and intensity of the fire. Indeed, [20] indicated that the selective loss of the fine soil fraction resulting from fire-induced erosion could lead to an increase in the coarse fraction of the soil. Similarly, the destruction by fire of the organic compounds that bind the mineral particles of the sand aggregates between them causes them to be destroyed and, consequently, an increase in the amount of fine particles.

\subsection{Effect of Early Fire on the Ground}

The results of our study show that early fire did not significantly alter soil chemistry, including $\mathrm{pH}$, total carbon, total nitrogen, total phosphorus, carbon-nitrogen ratio and cation exchange capacity. These results could be explained mainly by the fact that, despite the variation in fuel quantity, the measured fire temperatures were statistically similar in all the plots. It has been observed that soil temperature, which is closely related to heat from combustion, strongly affects soil properties [21]. But [22] estimate that only 5\% of all energy released by fire is transmitted to the ground. This reinforces our argument that, therefore, the low temperatures received could well explain the results obtained. The values of $\mathrm{pH}$, total carbon, total nitrogen and cation exchange capacity decrease significantly with the depth of soil sampling. The high values measured for the $0-5 \mathrm{~cm}$ superficial horizon could be due to the accumulation of ash, which is rich in nutrients. In fact, some nutrients accumulated in the aboveground plant biomass and litter is deposited with the ashes, which, depending on the severity of the fire, contain various amounts of nutrients [21]. In addition, dead roots and twigs could be an additional source of soil carbon. However, the fire did not induce significant changes in the amounts of soil carbon. These results are in agreement with the observations already noted by [23]. On the other hand, the total nitrogen, total phosphorus and $\mathrm{pH}$ values have significantly decreased after the passage of fire, contrary to what is reported in other studies [10]. The increase in $\mathrm{pH}$ is usually explained by the presence of ash, the accumulation of potassium, sodium hydroxide, magnesium, calcium carbonate, but also by the destruction of certain groups of acids contained in the organic matter [24]. However, at elevated temperatures, these components tend to evaporate or volatilize. The temperature reached in the present study was around $657^{\circ} \mathrm{C}$, which may have resulted in the loss of some ions and the subsequent decrease in $\mathrm{pH}$. Nitrogen levels were also reduced after fire, most likely because of rapid volatilization loss. Indeed, as early as $200^{\circ} \mathrm{C}$ nitrogen is easily lost as gas and ash [25] and at $500^{\circ} \mathrm{C}$, more than half of the nitrogen is lost to the atmosphere. Phosphorus can also be lost through volatilization [13]. In general, the results indicated significant interannual variation in $\mathrm{pH}, \mathrm{CEC}$ and total phosphorus. Since the impact of fire depends on environmental conditions during the fire, the year-to-year change in fuel quantity and the variation in rainfall over the three years may explain the variation in fire effects on soil parameters.

\subsection{Effect of Fire on the Dynamics of Phosphorus and Nitrogen}

The results of the study showed a slight increase in mineral nitrogen and total potassium, but this is not statistically significant. These results corroborate those of previous studies in a similar environment [26] which showed that after fire, there is an increase in the accumulation of $\mathrm{NH}_{4}^{+}$and potassium due to decomposition under the effect of fire, organic compounds binding the mineral particles. [4] reported an increase in $\mathrm{NH}_{4}{ }^{+}$in the range of $77 \%$ while Scharenbroch et al. (2012) report a 30\% increase for $\mathrm{NO}_{3}{ }^{-}$after fire. This phenomenon can be attributed to the pyrolysis during which the organic nitrogen, mainly the amino acids contained in the vegetable matter and the litter, takes a volatile gaseous form, of type $\mathrm{NH}_{3}$ (ammonia), molecular nitrogen or various oxides of nitrogen. The amount of ammonium measured in the second and third year, including in the control plot, was more than half that of the first year of study. This is probably due to volatilization phenomena, loss of nitrogen in soluble form, and / or leaching and leaching [13]. In contrast, an increase in nitrates $\left(\mathrm{NO}_{3}{ }^{-}\right)$ was observed, consistent with previous results in other ecosystems [27]. This increase is the result of mineralization and nitrification processes. The results showed a decrease in assimilable phosphorus by 
following the depth of soil sampling. However, an increase of this same parameter was observed after the passage of fire. This increase could be explained by the effect of mineralization and the addition of ash that is rich in nutrients [11]. The heat could also be at the origin of this increase. Temperatures convert phosphorus to orthophosphate (most assimilable form) thus contributing to the increase of phosphorus availability after the passage of fire. In addition, the increase in nutrient availability due to ash deposition is largely limited to shallow horizons; which explains the low concentration of available phosphorus in the $10-15 \mathrm{~cm}$ horizon.

\section{CONCLUSION}

This study made it possible to elucidate the modifications induced in the physicochemical properties of the soil by the early fire. The results showed that the highest temperatures measured reached $657 \pm$ $36^{\circ} \mathrm{C}$ and the early fire did not significantly modify the chemical characteristics of the soil. No significant difference was observed between the profiles, either before or after the fire. The average values of $\mathrm{pH}$, total carbon and carbon-nitrogen ratio in all fuel treatments oscillate respectively by 6; $5 \mathrm{~g} / \mathrm{kg}$ and 16 . Depending on the depth of soil sampling, a decrease of $2 \%, 4 \%$ and $5 \%$ of the total phosphorus was observed respectively for $0-5 \mathrm{~cm}$ horizons; $5-10 \mathrm{~cm}$ and $10-15 \mathrm{~cm}$. These observed variations as a function of the soil sampling depth and the amount of the fuel are due to the accumulation of nutrients from combustion of the fire and deposited in the form of ash on the soil surface. However, spatial variation in fire temperature could affect soil properties differently, and help to create a new spatial distribution of soil nutrients. Consequently, the effect of early fire on soil processes is generally variable and no general trend can be identified. Nevertheless, early fires known as forest management tools can therefore be considered as modulating factors of nutrient dynamics in Sudanian savannah soils. A long-term investigation taking into account the biological aspects of the soil should be conducted and could further elucidate the effects of early fires on the soil and its chemical components.

\section{ACKNOWLEDGEMENT}

The authors acknowledge their gratitude to the University of Sarh for its financial contribution and for the analytical laboratory that it left to our availability for this research. The authors also wish to thank the staff of the Department of Forests and Reforestation as well as the heads of the decentralized services of the State for their promptness to all our requests.

\section{REFERENCES}

[1] Keeley, J.E., Bond, W.J., Bradstock, R.A., Pausas, J.G., Rundel, P.W., Fire in Mediterranean Ecosystems: Ecology. Cambridge University Press (2012).

[2] Bekdouche, F., Evolution after fire of the synergetic ecosystem of Kabylia (northern Algeria). PhD thesis in Agronomic Science. Mouloud MAMMERI University of Tizi - Ouzou (Algeria), Faculty of Biological Sciences and Agronomic Sciences.Pp. 175 (2010).

[3] Sawadogo, L., Tiveau, D., Nygard, R., Influence of selective tree cutting, livestock and prescribed fire on herbaceous biomass in the savannah woodlands of Burkina Faso, West Africa. Agriculture, Ecosystems \& Environment International 105, 335-345 (2005).

[4] Doamba, S.W.M., Patrice SAVADOG and Hassan Bismarck NACRO., Role of savanna fires on the biogeochemical characteristics of soils in the Sudanian zone of Burkina Faso. Int. J. Biol. Chem. Sci. 8 (2): 777-793 (2014).

[5] Mills, A.J., Fey, M.V., Frequent fires intensify soil crusting: physicochemical feedback in the pedoderm of long-term burn experiments in South Africa. Geoderma 121, 45-64 (2004).

[6] Verma, S., Jayakumar, S., Impact of forest fire on physical, chemical and biological properties of soil: A review. Proceedings of the International Academy of Ecology and Environmental Sciences 2, 168-176 (2012).

[7] Ulery, A.L., Graham, R.C., Forest fire effects on soil color and texture. Soil Science Society of America Journal 57, 135 - 140 (1993).

[8] Ketterings, Q.M., Bigham, J.M., Soil color as an indicator of slash-and-brun fire severity and soil fertility in Sumatra, Indonesia. Soil Science Society of American Journal 64, 1826 - 1833 (2000).

[9] Neary, D.G., Ryan, K.C., DeBano, L.F., Wildland Fire in Ecosystems: Effects of Fire on Soils and Water. U.S (2008).

[10] Aref, I.M., Atta, H.A., Ghamade, A.R., Effect of forest fires on tree diversity and some soil properties. International Journal of Agriculture and Biology 13, 659-664 (2011). 
[11] Schafer, J.L., Mack, M.C., Short-term effects of fire on soil and plant nutrients. Plant Soil, $433-447$ (2010).

[12] Stoof, C.R., Weaseling, J.G., Ritsema, C.J., Effects of fire and ash on soil water retention. Geoderma 159, 276-285 (2010).

[13] Badia, D., Marti, C., Aguirre, A.J., Aznar, J.M., Gonzalez-Pérez, J.M., De la Rosa, J.M., Leon, J., Ibarra, P., Echeverria, T., Wildfire effects on nutrients and organic carbon of a Rendzic Phaeozem in NE Spain : Changes at cm-scale topsoil. Catena 113, 267-275 (2014).

[14] Parker, J.L., Fernandez, I.J., Rustad, L.E., Norton, S.A., Effects of Nitrogen Enrichment, Wildfire, and Harvesting on Forest-Soil Carbon and Nitrogen. Soil Sci. Soc. Am. J. 65, 1248-1255 (2001).

[15] DeBano, L.F. Neary, D.G., Effects of fire on soil, in: Eds DG Neary, K.R., LF DeBano (Ed.), Wildland Fire in Ecosystems: Effects of Fire on Soil and Water. USDA Forest Service, Rocky Mountain Research Station, General Technical Report RMRS-GTR, pp. pp. 21 - 92 (2005).

[16] Trollop, W.S.W., Potgieter, A.L.F., Fire behavior in the Krugger National Park. Journal of the Grassland Society of South Africa 2, 17-22 (1985).

[17] Guiguindibaye, M., Belem, M.O., Boussim, J.I., Characteristics of fires in a Sudanian savanna fire in Chad. International Journal of Biological and Chemical Sciences 7, 1147-1156 (2013).

[18] Savadogo, P., Sawadogo, L., Tiveau, D., Effects of grazing intensity and prescribed fire on soil physical and hydrological properties and pasture yield in the savanna woodlands of Burkina Faso. Agriculture, Ecosystems and Environment 118, 80-92 (2007).

[19] Sow, M., Hély, C., Mbowa, C., Sambou, B., Fuel and fire behavior analysis for early-seaso prescribed fire planning in Sudanian and Sahelian savannas. Journal of Arid Environment 89, 84-93 (2013).

[20] DeBano, L.F., Neary, D.G., Ffolliott, P.F., Fire's effects on ecosystems. John Wiley \& Sons Inc. New York. USA, Pp. 333 (1998).

[21] Certini, G., Nocentini, C., Knicker, H., Arfaioli, P., Rumpel, C., Wildfire effects on soil organic matter quantity and quality in two fire-prone Mediterranean pine forests. Geoderma 167-168, 148-155 (2011).

[22] Raison, R.J., Woods, P.V., Soil temperature during and tollowing low-intensity prescribed burning in a Eucalypt forest. Australian Journal of Soil Research 24, 33-47 (1986).

[23] Dembélé, F., Masse, D., Yossi, H., Effect of bushfire management on weed dynamics and soil quality on short fallows in the soudanian zone of Mali. In: Floret, C. (Ed.) ORSTOM, Dakar/Senegal (1997).

[24] Giovannini, G., Fire in agricultural and forestall ecosystem: The effects on soil. Edizioni ETS, Pisa, Italy (2012).

[25] Christensen, N.L., The effect of fire on physical and chemical properties of soil in Mediterranean-climate shrublands. in J.M. Moreno and W.C. Oechel, editors. The role of fire in Mediterranean-type ecosystems. Springer-Verlag, New York, New York, USA. 79-95 (1994).

[26] Prieto-Fernandez, A., Carballas, M., Carballas, T., Inorganic and organic N Pools in soils burned or heated: immediate alteration and evolution after forest wildfires. Geoderma 121, 291-306 (2004).

[27] Scharenbroch, B.C., Nix, B., Jacobs, K.A., Bowles, M.L., Two decades of low-severity prescribed fire increases soil nutrient a availability in a Medwestern, USA oak (Quescu) forest. Geoderma 183-184, 80-91 (2012).

Citation: Guiguindibaye Madjimbe, et.al. (2019). "Impact of Early Fires on Soil Physicochemical Properties in Sudan Savanna in Chad" International Journal of Research Studies in Agricultural Sciences (IJRSAS), 5(2), pp.7-17, http://dx.doi.org/10.20431/2454-6224.0502002

Copyright: (C) 2019 Authors. This is an open-access article distributed under the terms of the Creative Commons Attribution License, which permits unrestricted use, distribution, and reproduction in any medium, provided the original author and source are credited. 